\title{
The Investigation of Politeness Principles and Strategies Used in Akeelah and the Bee Movie
}

\author{
Esa Nur Hikmahwati ${ }^{1}$, Dhafid Wahyu Utomo ${ }^{2}$, Sutrisno Sadji Evenddy ${ }^{3}$ \\ ${ }^{1,2,3}$ Universitas Sultan Ageng Tirtayasa \\ 1esanurhikmahwati@gmail.com, 201hafid.wu@untirta.ac.id, ${ }^{3}$ sutrisno.se@untirta.ac.id

\begin{tabular}{ccc}
\hline Diterima & Direvisi & Disetujui \\
$26-12-2020$ & $23-02-201$ & $01-03-2021$ \\
\hline
\end{tabular}

\begin{abstract}
This research was aimed to investigate what kind of politeness principle and most dominant type applied in the tterances of the main characters' Akeelah and the Bee movie and strategies applied in their utterances of the main characters' Akeelah and the Bee movie. A descriptive qualitative was employed in this research. It concerned with the description of the data in the form of utterances produced by the characters in which politeness principles and strategies exist. There were two sources in this research. The primary source was the script of the movie. The secondary sources were books. The results of this research were: first, the main characters applied agreement maxim, approbation maxim, tact maxim, modesty maxim, and sympathy maxim in their utterances and the most dominant type used is agreement maxim. Second, in the application of politeness strategies, the main characters applied Bald-on-record, positive politeness, negative politeness and off-record in their utterances.
\end{abstract}

Keywords: Akeelah and the Bee, politeness principles, politeness strategies.

Abstrak - Penelitian ini bertujuan untuk meneliti prinsip-prinsip kesopanan apa saja yang digunakan dalam tuturan karakter utama pada film Akeelah and the Bee dan jenis paling dominan yang diterapkan dalam ucapan karakter utama pada film Akeelah and the bee dan strategi yang diterapkan dalam ucapan karakter utama film Akeelah and the Bee. Metode yang digunakan dalam penelitian ini adalah metode kualitatif deskriptif. Metode ini berkaitan dengan deskripsi data dalam bentuk tuturan yang diucapkan oleh karakter utama di mana prinsip dan strategi kesopanan ada di dalam kata yang dituturkan. Terdapat dua sumber dalam penelitian ini. Sumber utama adalah naskah film. Sumber sekunder adalah buku. Hasil penelitian ini adalah: pertama, karakter utama menerapkan tact maxim, approbation maxim, tact maxim, modesty maxim, dan sympathy maxim dalam ujaran mereka dan jenis yang paling dominan digunakan adalah agreement maxim. Kedua, dalam penerapan strategi kesopanan, karakter utama menerapkan bald-on-record, positive politeness, negative politeness dan off-record dalam tuturan mereka.

Kata kunci: Akeelah and the Bee, prinsip-prinsip kesopanan, strategi kesopanan.

\section{INTRODUCTION}

Being polite is one of the most important and vital portions of human communication. The ability to choose the appropriate utterances in a given discourse appears to be very important for everyone. The lack of knowledge and failure to do so may culminate in a mutual unintelligibility and even serious communication breakdown and one may be perceived as person who is rude or insensitive (Allami \& Naemi, 2010; Sukma \& Utomo, 2017; Yang \& Wannaruk, 2018; Rahayu, 2019). Therefore, politeness is very valuable as it can lead to certain attitude with others.

Interestingly, in everyday situation, what speaker is going to utter is not always the same as what they mean. There is a plethora of meaning behind the form of utterances. In this case, the interlocutor has to be able to interpret the implicit meaning stated by the speaker. There are some tacit rules bringing in within the utterances. Started from this point, it is exciting to bring up this language phenomenon to be further investigated. Hence, it is interesting to look more into the language impact on the way people communicate with each other. So, the study politeness is under the investigation of pragmatic study since it is dealing with how speaker convey their meaning in real life situation (Levinson, 1983; Yule, 2005).

According to Watt $(2003: 10)$ politeness in pragmatics is different from an everyday understanding of it and focusing almost uniquely on polite language in the study of verbal language. One must aware of both co-text and context as well as culture as politeness may different from one to the others. Based on (Lakoff, 1973), "politeness is a system of interpersonal relations designed to facilitate interactions by minimizing the potential of 
conflicts and confrontational tendencies in all human interactions" (p.34). Being polite means employing awareness of other's feelings. Being linguistically polite involves speaking to people appropriately in the right place and time (Johnson et al., 1988).

With the rapid development of technology, not only can the phenomena of politeness in an utterance be observed directly in real conversation, but also it can be observed easily through a movie. Movie is nowadays becoming one of the popular media as well as one of the data sources for linguistic study especially in observing politeness. Researchers can easily depict the use of politeness from the utterances produced by the characters in the movie. This invite and becomes current trend for some researchers to conduct an analysis using movie as the main data source (e.g. Winerta, Hamzah \& Sari, 2012; Mu, 2015; Mulyono, 2016; Rosari, 2016).

One of the movies that has been the main data source for politeness study is Akeelah and the Bee movie by Hawa \& Sukmaningrum (2011). This study discusses the level of directness in performing act of apology and the various way in conveying apology between the characters. However, this study has not discussed about the use of politeness maxim and politeness strategy but only focused on the level of directness. Based on the researchers' point of view, there should be another study with the same data source to get more comprehensive discussion about politeness phenomena used in Akeelah and the Bee movie. Therefore, this study seeks to answer this question as well as to fill this research gap.

\section{RESEARCH METHODOLOGY}

Descriptive qualitative approach was employed to conduct this study. It is chosen because it is advantageous in situations where limited information is available and the flexibility for future exploration in the area of research is desirable. Creswell (2012) states that the aim of qualitative research is more descriptive than predictive. The purpose of this research is to identify the politeness principles and strategies which could be applied in other real-life situations. It was concerned with qualitative research since it aims to understand human behavior and the reason that govern such behavior as it is (Denzin and Lincoln, 2005).

The main data observed in this study was the script of Akeelah and the Bee taken from http://www.scripts.com/script/akeelah and the bee 2383. According (Moleong, 2017), in qualitative research method, the researchers play as designers, data collectors, analysts, data interpreters, and reporters of the results. Researchers are the main and primary instrument because they planned the research; collected, classified, and analyzed the data; made an interpretation and conclusion from the data; and finally, reported the results.

The secondary instrument of this research is the datasheet which is used to note the linguistic phenomena found in the form of utterances from the main character in Akeelah and the Bee.

The method of data analysis in this research is based on (Moleong, 2017) qualitative data analysis theory (p.280). The utterances are analyzed by applying the following techniques or procedures. (a) Transcribing, in transcribing the data, the researchers tried to keep the data as simple as possible in order to facilitate the data analyze, such as labeling the speakers using letters, numbering the lines or the clause, and inserting contextual information to explain essential aspect. The researchers labeled each utterance with ' $\mathrm{P} 1$ ', and 'P2'. P1 refers to Akeelah's utterance, and P2 refers to Dr. Larabee's utterance. (b) Identification, In this step, the researchers identifies the smallest unit from transcribed data which is having meanings that relevance to the focus and problem of research by reading the transcripts repeatedly. After finding some smallest units that indicate to the politeness principles and strategies the researchers make some codes. The coding process based on the following conditions: the first column is a serial number of utterances, and the second column is a conversation between the main characters. The third column is the kind of politeness principles or strategies and the last column is the explanation from the utterances. (c) Classification, a process of slicing and splitting the data based on their categories (Moleong, 2017). All topics related to the focus of research is first listed. After completing the list, the identified topics are classified by slicing and splitting them based on their characteristics. In this process, the researchers classified the data based on Leech's politeness principles and Brown and Levinsons' politeness strategies. (d) Analyzing, analyzing that conducted in this study is to investigate the kinds and the reasons of using the politeness principles and strategies used by the main characters in Akeelah and the Bee movie. Finally, the results of classifying are analyzed based on the research questions. Data have been obtained will be analyzed qualitatively and described in the descriptive form. 


\section{FINDINGS AND DISCUSSION}

In this part the researchers display the finding data and then analyzed. The finding data was gotten from the film observation.

\section{Types of Politeness Principles used by Main Characters in Akeelah and the Bee Movie}

The findings of the types of the politeness principle applied in Akeelah and the Bee in term of the frequency of occurrence are presented below.

Table 3 Types of Politeness Principles used in Akeelah and the Bee Main Characters

\begin{tabular}{|c|c|c|c|c|c|c|c|}
\hline \multirow[t]{3}{*}{$\mathrm{N}$} & Charact & \multicolumn{5}{|c|}{ Politeness Principles } & \multirow{3}{*}{$\begin{array}{r}\text { Tot } \\
\text { al }\end{array}$} \\
\hline & ers & & & & & & \\
\hline & & $\begin{array}{l}\mathrm{T} \\
\mathrm{M}\end{array}$ & $\begin{array}{l}\mathrm{A} \\
\mathrm{M}\end{array}$ & $\begin{array}{l}\mathrm{M} \\
\mathrm{M}\end{array}$ & $\begin{array}{l}\mathrm{AG} \\
\mathrm{M}\end{array}$ & $\begin{array}{l}\mathrm{S} \\
\mathrm{M}\end{array}$ & \\
\hline 1 & Akeelah & 2 & 2 & 0 & 4 & 1 & 9 \\
\hline 2 & $\begin{array}{l}\text { Dr. } \\
\text { Larabee }\end{array}$ & 2 & 7 & 3 & 4 & 0 & 16 \\
\hline \multicolumn{2}{|c|}{ Total } & 4 & 9 & 3 & 8 & 1 & 25 \\
\hline \multicolumn{2}{|c|}{ Percentage } & $\begin{array}{l}16 \\
\%\end{array}$ & $\begin{array}{l}36 \\
\%\end{array}$ & $\begin{array}{l}12 \\
\%\end{array}$ & $\begin{array}{l}32 \\
\%\end{array}$ & $\begin{array}{l}4 \\
\%\end{array}$ & $\begin{array}{l}100 \\
\%\end{array}$ \\
\hline
\end{tabular}

Five politeness principles are found to be used by the main characters. These principles are Tact Maxim, Approbation Maxim, Modesty Maxim, Agreement Maxim, and Sympathy Maxim.

Twenty-seven utterances from the main characters in Akeelah and the Bee which could represent politeness principles are identified and classified. In the movie, tact maxim occurs four times $(16 \%)$, approbation maxim occurs nine times $(36 \%)$, modesty maxim occurs three times $(12 \%)$, agreement maxim occurs eight times (32\%), and sympathy maxim occurs one time (4\%).

Based on these data, it can be concluded that approbation maxim is uttered the most and the dominant type of politeness principle used by the main characters. For this principle, Dr. Larabee also applies it more than Akeelah does. Since Dr. Larabee is the mentor, he applies this principle to make Akeelah feels appreciative when she does a good job. On the other hand, Akeelah applies this maxim to praise Dr. Larabee for being a good mentor. One of the conversation that contains approbation maxim is as follow.
P1 : I can't learn 5000 new words all by my self. (b.6)

$\mathrm{P} 2 \quad:$ Oh, yes, you can. You've got a brain like a sponge. (b.7) You just sit down and you study them.

After analyzing code (b.6 \& 7), code (b.6) was showed that assertive category of complaining expression because the speaker state a complaining words to the listener's act and code 7 was showed expressive category of praising expression because the speaker give a praise to the listener.

The second most used politeness principle is the agreement maxim is used the most in Akeelah and the Bee because when the main characters are conversing, they are trying to be on the same terms with each other despite their differences. These are found mostly in Dr. Larabee's utterances during his conversations with Akeelah. This may be attributed to the fact he is the mentor for her; hence he would try to create a comfortable atmosphere between them. One of the conversation that contains agreement maxim is as follow.

P1: I learned all the winning words since 1925 just like you said I should. Sorry for being so insolent last time. That's not gonna happen no more. Any more. I promise. I was wondering if you might reconsider coaching me for the state bee. Cause I need a coach bad.

P2: Badly. You need a coach badly. Come in. Come in, come in. (d.1)

Code (d.1) here indicates that the speaker is applying agreement maxim in the communication to others. In this conversation, it was found that the speaker (Akeelah) used agreement maxim by saying,"I was wondering if you might reconsider coaching me for the state bee. Cause I need a coach bad". The speaker tried to ask the listener to be her coach for the speeling bee competition. The listener (Dr. Larabee) agreed and give her (akeelah) an instruction. By looking at the respond, the speaker succeeded in using the politeness principles to get the listener's responses.

Tact maxim is the third most used principle in this movie. Both main characters use tact maxim when they help each other because they want to keep their relationship pleasant. One of the conversation that contains tact maxim is as follow.

P1: I learned all the winning words since 1925 just like you said I should. Sorry for being so insolent last time. That's not gonna happen no more. Any more. I promise. I was wondering if you might reconsider coaching me for the state bee. Cause I need a coach bad. (a.1)

P2: Badly. You need a coach badly. Come in. Come in, come in. (a.2) 
Code (a.1 \& 2) indicates that the speakers are applying tact maxim in communication to others. The code a.1 utterance "I promise. I was wondering if you might reconsider coaching me for the state bee. Cause I need a coach bad." is a commissive category of illocution as promising. For the code a.2 utterance "Badly. You need a coach badly. Come in. Come in, come in." Is a directive category of illocution as advising and commanding. The word badly is an advising expression because the speaker give an advice of a correct grammar to listener while Come in. Come in, come in is a commanding expression because the speaker command the listener to come. Thus, those words can avoid a rude attitude toward the listener.

The fourth position appears in the utterances of the characters is modesty maxim. Only Akeelah has talked with this principle. This is due to Akeelah's humble attitude when speaking to Dr. Larabee. One of the conversation that contains approbation maxim is as follow. One of the conversation that contains modesty maxim is as follow.

P2 : Yes, please put that down. Just-yeah. Have you, have you got any goals?

P1 : Hmm?

P2 : Goals, what would you like to be when you grow up? A doctor, a lawyer, a standup comic. P1 : I don't know. The only thing I'm good at is spelling. (c.1)

This utterance indicates that the speaker tried to minimize the expression of praise of self and maximize of dispraise of self when the listener asked her.

The least politeness principle used in this movie is sympathy maxim. It is only used once by Akeelah. This is done to minimize friction and enhances the sympathy between both of them so conflicts could be avoided. One of the conversation that contains sympathy maxim is as follow.

P1 : I spelled- over and over again. And I'd feel better. Maybe when you're thinking of her... you can try spelling. It might help. (e.1)

P2 : Akeelah? Who told you?

P1 : You did. You called me by her name. That's her jump rope, isn't it?

P2 : Yes.

P1 : What happened to her?

P2 : She got very sick. She was only a couple of years younger than you when she passed.

The statement above showed that the speaker (Akeelah) commiserate to the listener (Dr.Larabee). Akeelah tried to minimize antipathy between them and giving sympathy to Dr. Larabee.

\section{The Most Dominant Type Used by The Main Characters' Utterance}

There are six maxims as the types of politeness principle (Leech, 2014). They are tact maxim, generosity maxim, approbation maxim, modesty maxim, agreement maxim and sympathy maxim. In this study, the researchers analyzed the data aid found one kind of those politeness principles was dominantly used in the main characters' utterances in directive and expressive speech acts. The researchers tried to show the dominant Politeness Principle by using percentage of each maxim. It was showed in the table as the following:

Table 4 The Percentage of Politeness Principles in Main Characters' Utterance

\begin{tabular}{|l|l|l|}
\hline $\begin{array}{l}\text { Politeness } \\
\text { Principles }\end{array}$ & $\begin{array}{l}\text { The } \\
\text { Occurences }\end{array}$ & Percentage \\
\hline Tact maxim & 4 & $16 \%$ \\
\hline $\begin{array}{l}\text { Approbation } \\
\text { maxim }\end{array}$ & 9 & $36 \%$ \\
\hline Modesty maxim & 3 & $12 \%$ \\
\hline $\begin{array}{l}\text { Agreement } \\
\text { maxim }\end{array}$ & 8 & $32 \%$ \\
\hline $\begin{array}{l}\text { Sympathy } \\
\text { maxim }\end{array}$ & 1 & $4 \%$ \\
\hline Total & 25 & $100 \%$ \\
\hline
\end{tabular}

The table above showed that approbation maxim was dominantly used in main characters' utterances in communication among other. This was because both Akeelah and Dr. Larabee wants to minimizing dispraise of other and maximize praise of other especially Dr. Larabee who does more utterance used this maxim in the conversation.

\section{Types of Politeness Strategies in Akeelah and the Bee Movie}

Politeness strategy is the strategy of how people lessen the threat to other's face (Brown \& Levinson, 1988). Brown and Levinson offer a descriptive analysis of strategies used by the participants to maintain their perspective faces in social (Lakoff \& Ide, 2005). Brown and Levinson found 4 politeness strategies. Those are bald on record, positive politeness, negative politeness and off record. The frequency of occurrence of the politeness strategy used by each character of Akeelah and the Bee in using each politeness strategy is described in the table below.

Table 5 Findings of Politeness Srategies used in Akeelah and the Bee Main characters 


\begin{tabular}{|c|c|c|c|c|c|c|}
\hline \multirow{2}{*}{ NO } & \multirow{2}{*}{ Characters } & \multicolumn{4}{|c|}{ Politeness Strategies } & \multirow{2}{*}{ Total } \\
\cline { 3 - 6 } & & BR & PP & NP & OR & \\
\hline 1 & Akeelah & 7 & 6 & 6 & 3 & 22 \\
\hline 2 & Dr. Larabee & 9 & 10 & 1 & 4 & 24 \\
\hline Total & 16 & 16 & 7 & 7 & 46 \\
\hline Percentage (\%) & $34,78 \%$ & $34,78 \%$ & $15,21 \%$ & $15,21 \%$ & 100 \\
\hline
\end{tabular}

situation know each other fairly well. This strategy is used to minimize the distance between them by expressing friendliness and solid interest in the hearer's need to be respected. On the other hand, this is one of the conversation that contains positive politeness

Table 5 shows the occurrence of politeness strategies applied by the main character of Akeelah and the Bee movie. Based on the findings, there are forty-six utterances which could represent politeness strategies used by the main characters in Akeelah and the Bee. Bald-on-record and positive politeness each occurs sixteen times (34,78\%), follows by negative politeness and off-record which both occurs seven times $(15,21 \%)$ each.

Bald-on-record and positive politeness are the politeness strategies mostly used in this movie. Bald on record strategy is the conformity of Grice's conversational maxims. A speaker applied this strategy in the situation where maximum efficiency is needed in communication. This strategy is also commonly found in people who know each other very well and are very comfortable in their environment, such as between close friends and families. This type of strategy is performed directly, clearly, and unambiguously. Dr. Larabee uses positive politeness more than Akeelah does because he wants to be friendly by eliminating the gaps between them. He also uses bald-on-record more than Akeelah does as he is the person who utters directly, clearly, and unambiguously to the listener. Here, one of the conversation that contains bald on record is as follow.

P2 : Listen, you got very lucky at the district bee. The competition at state level is much stronger. So, if you and I were to prepare for that, we'd have to do it on my schedule. So, we'd have to work three hours each morning starting at 9:00. Can you handle that?

P1 : Well, I do have summer school. But, Mr. Welch said working with you could take the place of it. (a.4)

In Code (a.4) Dr. Larabee does a task oriented to Akeelah. He directly request to Akeelah to do mentoring session on his schedule. For that reason, he uses bald on record strategy in this utterance. He directly request to the listener to do what they need for them.

Positive politeness which appplied as the same number as bald on record is defined as the way people create communicative relationship by creating rapport. The concept of rapport may be different since each person has his own understanding on being close to others. The positive politeness strategy is usually seen in groups of friends, or where people in the given social is as follow.

P1 : I learned all the winning words since 1925 just like you said I should. Sorry for being so insolent last time. That's not gonna happen no more. Any more. I promise. I was wondering if you might reconsider coaching me for the state bee. Cause I need a coach bad. (b.1)

P2 : Badly. You need a coach badly. Come in. Come in, come in.

Code (b.1) it indicates that Akeelah make a promise to Dr. Larabee. For that reason, the speaker applied Positive Politeness in her utterance because she tries to respect and make a closer relationship with the listener.

On the other hand, negative politeness and offrecord strategies are used considerably less than the positive and bald-on-record ones. Negative politeness is applied to create a communicative relationship by making a space between speaker and hearer. In the negative politeness, Akeelah is more dominant than Dr. Larabee. She generally applies this strategy in her utterances when she feels apologetic to Dr. Larabee or when she is not confident with her own ability. Here, one of the conversation that contains negative politeness is as follow.

P1 : I learned all the winning words since 1925 just like you said I should. Sorry for being so insolent last time. That's not gonna happen no more. Any more. I promise. I was wondering if you might reconsider coaching me for the state bee. Cause I need a coach bad. (c.3)

P2 : Badly. You need a coach badly. Come in. Come in, come in.

Code (c.2) indicates apologizing in negative politeness strategy. In this conversation, Akeelah apologizing to what she did before to Dr. Larabee. She felt really sorry about it and want Dr. Larabee to become her mentor. For this reason, Akeelah applied negative politeness strategy in apologizing.

In case of the off-record strategy, this strategy is used to show someone's face wants indirectly. Akeelah and Dr. Larabee use the strategy almost the same time. This is shown by their tendency to be indirect and use metaphors in their conversation. Here, one of the conversation that contains offrecord strategy is as follow. 
P2 : He's just a little robot memorizing lists of words. The people we are studying : DuBois, Dr.King, JFK, these people used words to change the world. And they didn't acquire their vocabulary by rote memorization. (d.3)

P1 : Okay.

Code (d.3) indicates that Dr. Larabee uses methapor by saying little robot. It means he uses off record in his utterance.

\section{CONCLUSION}

Based on the findings and discussions, the result of the research is summarized as follows. First, five politeness principles are found to be used by the main characters. These principles are Tact Maxim, Approbation Maxim, Modesty Maxim, Agreement Maxim, and Sympathy Maxim. Twentyseven utterances from the main characters in Akeelah and the Bee which could represent politeness principles are identified and classified. In the movie, tact maxim occurs four times $(16 \%)$, approbation maxim occurs nine times (36\%), modesty maxim occurs three times (12\%), agreement maxim occurs eight times $(32 \%)$, and sympathy maxim occurs one time (4\%).

Based on these data, it can be concluded that approbation maxim is uttered the most and is the dominant type of politeness principle used by the main characters. For this principle, Dr. Larabee also applies it more than Akeelah does. Since Dr. Larabee is the mentor, he applies this principle to make Akeelah feels appreciative when she does a good job. On the other hand, Akeelah applies this maxim to praise Dr. Larabee for being a good mentor.

The second objective of the research is to find out the politeness strategies applied by the main characters in Akeelah and the Bee. The utterances are classified based on the theory of politeness strategies by Brown and Levinson. These strategies are Bald-on-Record, Positive Politeness, Negative Politeness, and Off-Record.

Based on the findings, there are forty-six utterances which could represent politeness strategies used by the main characters in Akeelah and the Bee. Bald-on-record and positive politeness each occurs sixteen times (34,78\%), follows by negative politeness and off-record which both occurs seven times $(15,21 \%)$ each.

\section{REFERENCES}

Allami, H. \& Naeimi, A. (2011). A cross-linguistic study of refusals: An analysis of pragmatic competence development in Iranian EFL learners. Journal of Pragmatics, 43, 385406.https://doi.org/10.1016/j.pragma.2010.07. 010

Brown, P., \& Levinson, S. C. (1988). Politeness: Some Universals in Language Usage. In Interactional Sociolinguistic.

Creswell, J. W. (2012). Educational Research: Planning, conducting, and evaluating quantitative and qualitative research (C. Robb (ed.); 4th ed.). PEARSON. http://library1.nida.ac.th/termpaper6/sd/2554/ 19755.pdf

Denzin, N. K., \& Lincoln, Y.S. (2005). The handbook of qualitative research $\left(2^{\text {nd }}\right.$ ed.). London: Sage Publisher

F Hawa, R Sukmaningrum. 2011. The Level of Directness in Apologising in Akeelah and the Bee Movie Dialogue. ETERNAL (English Teaching Journal), 103.98.176.9/index.php/eternal/article/downl oad/449/405

Johnson, D. M., Yang, A. W., Brown, P., \& Levinson, S. C. (1988). Politeness: Some Universals in Language Usage (Studies in Interactional Sociolinguistics 4). TESOL Quarterly. https://doi.org/10.2307/3587263

Johnston, Scott W., V. D. D. (2011). Research method in everyday life. In Methods in molecular biology (Clifton, N.J.).

Lakoff, R. T. (1973). The logic of politeness; or, minding your p's and q's. In Papers from the ninth regional meeting of the Chicago Linguistic Society.

Lakoff, R. T., \& Ide, S. (2005). Intruduction: Broadening the horizon of linguistic politeness. In Pragmatics \& Beyond New Series.

Leech, G. (2014). The Pragmatics of Politeness. In The Pragmatics of Politeness. https://doi.org/10.1093/acprof:oso/978019534 1386.001.0001

Leech, G. (2016). Principles of Pragmatics. In Principles of Pragmatics. https://doi.org/10.4324/9781315835976

Levinson, Stephen C. 1983. Pragmatics. London: Longman.

Moleong, L. J. (2017). Metodologi Penelitian Kualitatif (Edisi Revisi). In PT. Remaja 


\section{Rosda Karya}

Mu, Yuting. 2015. The Application of Politeness Strategies in English and Chinese Movie Reviews. International Journal of English Linguistics. Vol (5) 6. doi:10.5539/ijel.v5n6p105

Mulyono, Eko. 2016. Politeness Principle Analysis in Cartoon Movie Entitled Stand by $\mathrm{Me}$ Doraemon. Premise Journal. Vol (5) 1

Rahayu, N. S. (2018). Refusal strategy performed by Indonesian EFL learners. Indonesian EFL Journal, 5(1), 67-76. doi: 10.25134/ieflj.v5i1.1612.

Rosari, Miwita. 2016. Politeness Strategies Applied by the Characters of The Great Debaters Movie LLT Journal: A Journal on Language and Language Teaching. Vol (19) 1. DOI: https://doi.org/10.24071/1lt.2016.190103

Sukma, B.P., Utomo, D.W. 2017. Interpersonal Metadiscourse In The Jakarta Post E-News Opinion Articles. Jurnal BEBASAN Jurnal Ilmiah Kebahasaan dan Kesastraan. Vol 3(1). $17-27$

Violen Winerta, Hamzah, Rima Andriani Sari. 2012. An Analysis of Politeness Strategies in Requesting Used in Real Human and NonHuman Conversation On "Avatar" Movie. EJournal English Language and Literature, 1(1) 1-12.

Watts, Richard J. (2003). Politeness. Cambridge University Press.

Yang, L., \& Wanaruk, A. (2018). A cross-cultural pragmatic study of the speech act of complaining. Kasetsart Journal of Social Sciences, $\mathrm{xxx}, 1-7$.

Yule, G. (2005). The study of language (3rd ed.). Cambridge University Press. 